\title{
Field Evaluation of Tomato Hybrids Engineered with Tomato spotted wilt virus Sequences for Virus Resistance, Agronomic Performance, and Pollen-Mediated Transgene Flow
}

\author{
Gian Paolo Accotto, Giuseppe Nervo, Nazzareno Acciarri, Luciana Tavella, Manuela Vecchiati, \\ Massimo Schiavi, Giovanna Mason, and Anna Maria Vaira
}

First, fifth, and eighth authors: Istituto di Virologia Vegetale, CNR, Strada delle Cacce 73, 10135 Torino, Italy; second and sixth authors:
Istituto Sperimentale per l'Orticoltura, CRA, S.o.p. Montanaso L., Via Paullese 28, 20075 Montanaso Lombardo (LO), Italy; third author:
Istituto Sperimentale per l'Orticoltura, CRA, S.o.p. Monsampolo, Via Salaria, 1, 63030 Monsampolo del Tronto (AP), Italy; fourth and
seventh authors: Di.Va.P.R.A. Entomologia e Zoologia applicate all'Ambiente, Università di Torino, Via L. da Vinci 44, 10095 Grugliasco (TO), Italy.

Current address of G. Mason: Istituto di Virologia Vegetale, CNR, Strada delle Cacce 73, 10135 Torino, Italy.

Accepted for publication 9 March 2005.

\begin{abstract}
Accotto, G. P., Nervo, G., Acciarri, N., Tavella, L., Vecchiati, M., Schiavi, M., Mason, G., and Vaira, A. M. 2005. Field evaluation of tomato hybrids engineered with Tomato spotted wilt virus sequences for virus resistance, agronomic performance, and pollen-mediated transgene flow. Phytopathology 95:800-807.

Tomato hybrids obtained from homozygous progeny of line 30-4, engineered for Tomato spotted wilt virus (TSWV) resistance, were tested under field conditions in two locations with their corresponding nontransgenic hybrids. No transgenic hybrid became infected, but 33 to $50 \%$ of plants of each nontransgenic hybrid became infected with a severe reduction of marketable fruit production. The transgenic hybrids conformed to the standard agronomic characteristics of the corresponding

used to estimate the flow of the transgene via pollen. No transgene flow was detected in the protected crops; however, in the open field experiment, $0.32 \%$ of tomato seedlings were found to contain the genetic modification. Immunity to TSWV infection in 30-4 hybrids was confirmed in laboratory conditions using mechanical inoculation and grafting. Thrips inoculation in leaf discs of line 30-4 demonstrated that TSWV replication was inhibited at the primary infection site but not in leaf discs of a commercial hybrid containing the naturally occurring resistance gene $S w$ 5. Due to the high economic value of tomato crops worldwide and the importance of TSWV, the engineered resistance described here is of practical value for breeding into cultivars of commercial interest, because it could be combined with naturally occurring resistance, thus greatly reducing the ability of the virus to develop resistance-breaking strains.
\end{abstract} nontransgenic ones. Fruit were collected from the nontransgenic plots included in the experimental field and from border rows, and seed were
Additional keywords: Italy, Tospovirus.
Tomato (Lycopersicon esculentum Mill.) is an important crop worldwide; however, in some areas, its cultivation is substantially limited by virus diseases. Tomato spotted wilt virus (TSWV), a member of the genus Tospovirus in the family Bunyaviridae (8), is an extremely polyphagous virus, which can infect more than 1,000 plant species (20) and can be devastating in tomato. TSWVresistant commercial hybrids with the $S w-5$ gene from Lycopersicon peruvianum (L.) Mill. (27) are available, but virus isolates capable of overcoming this resistance have been reported $(2,14$, 30). Therefore, it is important to explore other ways to obtain TSWV-resistant tomato plants.

Resistance to TSWV by genetically engineering plants with the TSWV nucleoprotein $(N)$ gene, first reported in 1991 on tobacco (9), has been demonstrated in several other species (1). Using Agrobacterium-mediated transformation (32), we have produced tomato plants with resistance to TSWV, with one line (30-4) demonstrating complete resistance. Molecular analysis of this line showed that it had a single transgene insertion locus containing at least three copies of rearranged $N$ gene sequences, and that TSWV N-specific aberrant transcripts, but not protein, were detectable $(17,19)$. The resistance of line $30-4$ prompted us to test it

Corresponding author: G. P. Accotto; E-mail address: g.accotto@ivv.cnr.it

DOI: 10.1094/PHYTO-95-0800

(C) 2005 The American Phytopathological Society at the hemizygous state (i.e., in hybrid progenies under field conditions) because a line can be considered for breeding programs only if resistance is maintained in hybrids in the field.

For the present work, we produced hybrids from line 30-4 and then compared them with the corresponding nontransgenic hybrids under field conditions for virus resistance and for agronomic performance. We also determined the transgene flow through pollen, and assessed insect populations during the resistance assay.

\section{MATERIALS AND METHODS}

Tomato hybrids. The production and analysis of transgenic line 30-4 has been described (19). Derived by genetic transformation of the fresh market tomato parental line L276-76 (hereafter abbreviated as 276), it combines high resistance to TSWV in laboratory tests, lack of transgenic protein production, and a single insertion locus.

$\mathrm{R}_{2}$ selfed progeny of line 30-4 were selected on kanamycin and selfed again to obtain $R_{3}$ progeny. $R_{3}$ progeny not segregating on kanamycin were analyzed on Southern blots following digestion of the genomic DNA with KpnI, BamHI, and XbaI (Fig. 1). They were considered homozygous because they did not segregate and all produced the same electrophoretic pattern. Transgenic $F_{1}$ hybrid seed were obtained by crossing the homozygous 30-4 plants with nontransgenic parental lines RT, INB, and H76PC (30-4 $\times$ RT, 30-4 × INB, and 30-4 × H76PC, respectively). Nontransgenic 
hybrids also were produced by crossing line 276 with lines RT, INB, and H76PC $(276 \times$ RT, $276 \times$ INB, and $276 \times$ H76PC, respectively) to obtain plants that, apart from the transgene, have the same genetic background. These combinations of parental lines produced hybrids with good characteristics for the fresh tomato market. Included in some experiments was cv. Valiente $\mathrm{F}_{1}$ (De Ruiter Seeds, NL), a commercial hybrid resistant to TSWV due to introgression of the $S w-5$ gene from $L$. peruvianum (27).

Field experiments for virus resistance and agronomic performance. Two field trials were conducted during spring to summer 1999 in different areas of Italy under authorization no. B/IT/99/05 from the Italian Ministry of Health. Standard agronomic practices were used, including mulching with plastic film. No insecticides were applied. The first trial was carried out in Albenga, northwestern Italy in an open field, and was designed for testing resistance to TSWV in an area where both the virus and its natural vector are widespread. The second trial was to evaluate the agronomic performance of the transgenic versus the nontransgenic tomato hybrids in the absence of TSWV infection. Therefore, it was performed under a plastic tunnel equipped with insect-proof nets in Monsampolo del Tronto, central Italy, an area where TSWV epidemics never were reported.

The same experimental design was applied to both trials. In all, 288 plants were tested in four randomized blocks. In each block, the six hybrids (three transgenic and three nontransgenic) were compared in elementary plots. Each elementary plot of $5 \mathrm{~m}^{2}$ consisted of 12 plants. The set of the four blocks was surrounded by a double row of 192 nontransgenic tomato plants. The open field trial was further bordered by a triple row of maize plants and a fence. Tomato plants that died during the course of the experiment were not replaced.

The transgenic hybrids used were 30-4 × RT, 30-4 × INB, and 30-4 $\times$ H76PC, whereas the nontransgenic hybrids were $276 \times$ RT, $276 \times \mathrm{INB}$, and either Valiente (resistance trial) or $276 \times$ H76PC (agronomic performance trial).

The trial for resistance was started in Albenga on 15 June by transplanting young tomato seedlings, and lasted until 8 September. To assure a source of inoculum, TSWV-infected plants infested by the thrips Frankliniella occidentalis (Pergande) were collected in nearby greenhouses and positioned in each plot. The larvae of $F$. occidentalis found on these infected plants were distributed throughout the plots. At 3, 5, 8, and 10 weeks after planting, plants showing virus symptoms were sampled for total RNA extraction and dot blot analysis. At 12 weeks, the end of the trial, all 288 plants were sampled and TSWV infection was evaluated using a tissue print assay. Total RNA was extracted from $200 \mathrm{mg}$ of leaf samples, using the RNAWIZ reagent (Ambion), according to the manufacturer's instructions. The final pellet was resuspended in $40 \mu \mathrm{l}$ of sterile water and stored at $-80^{\circ} \mathrm{C}$. For the dot blots, 5 and $0.5 \mu \mathrm{l}$ were spotted on nylon membranes and hybridized with a TSWV-NSm gene-specific probe. The probe was obtained by polymerase chain reaction (PCR) incorporating digoxigenin-11dUTP (PCR DIG Probe Synthesis Kit, Roche, Penzberg, Germany). The primers, designed on the TSWV RNA-M sequences available in the GenBank, were TS-NSM202+ (5'-GGAACCTATGARTCTGATTC-3') and TS-NSM847- (5'-CTGATCTCTCAAGATTTGAGC-3'). An N gene-specific probe was not used due to its possible reaction with the transgenic transcripts. For the tissue print assay, three leaf petioles from each tomato plant were spotted on $1-\mathrm{cm}^{2}$ squares of a nylon membrane. Dot blots and tissue prints were hybridized and detected with chemiluminescence as described previously (16).

Thrips populations were monitored $\approx 1,3,5,7$, and 10 weeks after the transplanting. During the surveys, three leaves per plant in the four central plants of each plot were observed, and both larvae and adults were counted. On the same leaves, generalist predators belonging to the order Hemiptera, suborder Heteroptera were monitored.
At the end of the experiment, all red fruit were harvested and yield, fruit number, and fruit weight were measured for each plot. Data were analyzed with standard statistical methods (analysis of variance).

The trial for agronomic performance started in Monsampolo on 29 March by transplanting tomato seedlings in the plastic tunnel, and lasted until 24 July. Yield, fruit number, and fruit weight were measured as early production (harvested between 14 and 24 June) and total production. Plants also were visually inspected to detect possible phenotypic differences between transgenic and nontransgenic hybrids.

Transgene flow evaluation. The amount of movement of the transgene via pollen was monitored in the two field trials described above, plus a third protected one, designed with the same format, in Albenga. To analyze transgene flow through pollen dispersion, 20 fruit were taken from each elementary plot of nontransgenic plants in every trial, as well as from the border rows, and seed were collected. In the open field trial, fruit were harvested at three different times. Seed were sown in sterilized soil in 54-hole plastic trays kept in a glasshouse at 17 to $21^{\circ} \mathrm{C}$. When seedlings reached the two true-leaf stage, they were sprayed with kanamycin (300 ppm antibiotic solution) twice a day.

The kanamycin-tolerance test sometimes is leaky, producing false positives, and the growth conditions of seedlings were not completely controlled in the glasshouse environment; therefore,
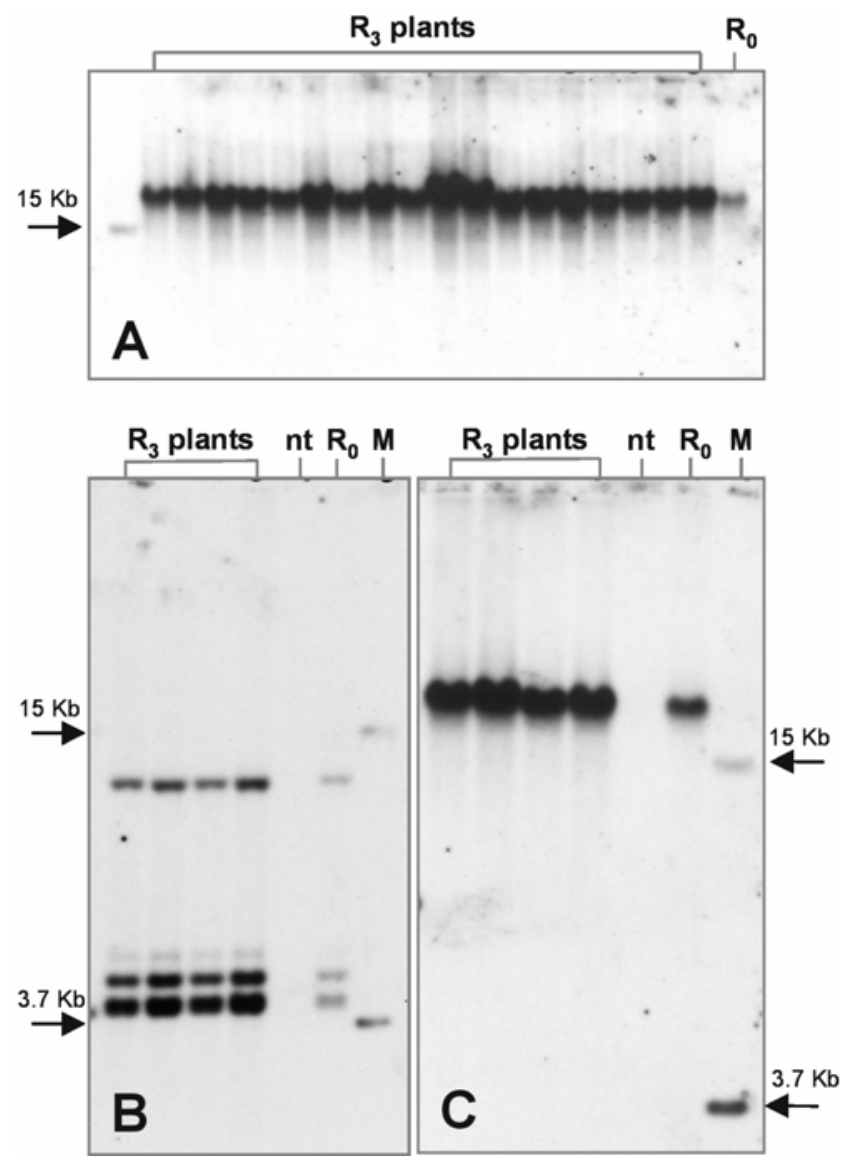

Fig. 1. Southern blots of restricted genomic $D N A$ of $R_{0}$ and $R_{3}$ transgenic plants together with nontransgenic controls. Restriction enzymes were chosen among those cutting once inside the T-DNA. Membranes were hybridized with an $N$-specific probe. Genomic DNAs were digested with A, KpnI, B, $X b a \mathrm{I}$, and $\mathbf{C}, B a m \mathrm{HI}$. The single bands observed in $\mathbf{A}$ and $\mathbf{C}$ indicate integration in a single locus, while the multiple bands obtained in $\mathbf{B}$ indicate the presence of multiple rearranged copies. In each panel, the pattern obtained with either $R_{0}$ or $R_{3}$ transgenic plants is the same. Size of DNA markers (M) is indicated by arrows on the sides. 
the nature of plants still green after the kanamycin treatment was further analyzed by a PCR method targeting the TSWV- $N$ gene. Total nucleic acids were extracted from each seedling; the extracts were tested by PCR using TSWV- $N$ gene-specific primers (32). As a control of DNA extraction, a portion of an endogenous tomato gene also was amplified: primers (APX2702+, 5'-GCCCTATTTGTACCGGTTAAC-3' and APX3005-, 5'-GCATAACGGAGAACAATCACC-3') specific for the tomato ascorbate-peroxidase $(A P X)$ gene were designed from the GenBank sequence Y16773. These primers amplify a 303-bp fragment. Amplifications of both TSWV- $N$ and $A P X$ were run in standard reactions, with an annealing temperature of $60^{\circ} \mathrm{C}$. PCR products were electrophoresed on $1.7 \%$ agarose gel and visualized by ethidiumbromide staining.

Leaf disc infection assays. In order to determine whether the resistance observed in hybrids derived from 30-4 differed functionally from that observed in the commercial hybrid containing the $S w-5$ gene, laboratory transmission trials were carried out using a leaf disc assay, essentially as described by Wijkamp et al. (33). A virus-free $F$. occidentalis population was reared in gauzecovered glass jars on green bean pods and pollen, as previously described (29). Larvae not older than $2 \mathrm{~h}$ were given an acquisition access period (AAP) of 48 to $72 \mathrm{~h}$ on leaves of Datura

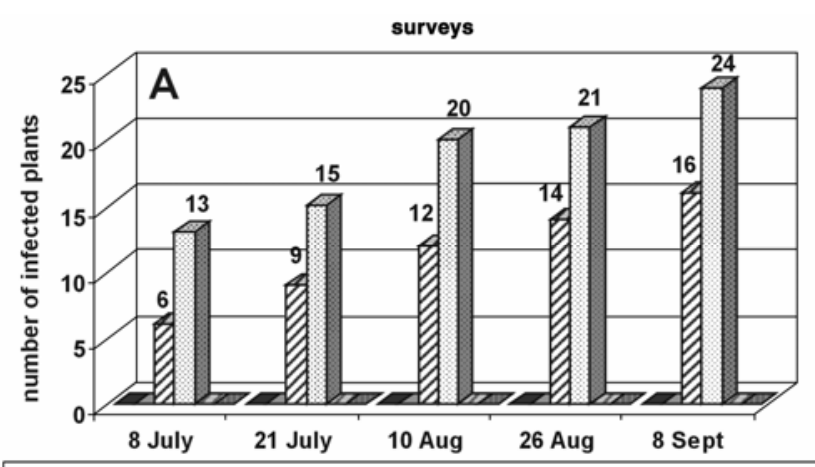

$\square 30-4 \times$ RT $\square 30-4$ x INB $\square 276$ x RT $\square 276$ x INB $\square 30-4 \times$ H76PC $\square$ Valiente

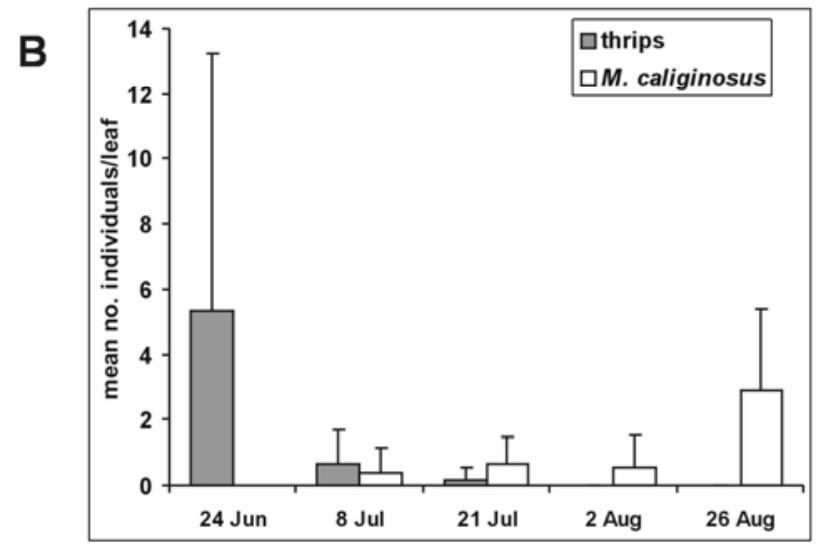

Fig. 2. Open field trial for virus resistance conducted in Albenga from 15 June to 8 September 1999. A, Time-course of Tomato spotted wilt virus (TSWV) infection. At 3 (8 July), 5 (21 July), 8 (10 August), and 10 (26 August) weeks after planting, plants showing symptoms were sampled and assayed for TSWV infection by dot blotting. At 12 weeks ( 8 September), all plants were sampled and assayed by tissue printing. Total number of plants in the resistance trial $=288$. TSWV-infected plants were found among nontransgenic hybrids only. B, Population dynamics of thrips vectors and the generalist predator Macrolophus caliginosus monitored at various time intervals. Thrips (larvae and adults) and $M$. caliginosus (nymphs and adults) were monitored on three leaves/plant in the four central plants of each elementary plot. Data represent the total combined for all genotypes. Standard deviation values are shown. stramonium L. systemically infected by TSWV P105 (from the IVV collection, originally isolated in Liguria, Northern Italy, from pepper) in cages (28). The larvae then were transferred to other cages on healthy cucumber until adulthood. One day after emergence, each adult was put in an Eppendorf tube $(1.5 \mathrm{ml})$ containing a leaf disc (12 mm in diameter) of one tomato hybrid (30-4 $\times$ INB, $276 \times$ INB, or Valiente) or homozygous 30-4 for a 48- to $72-\mathrm{h}$ inoculation access period (IAP). Then the leaf disc was removed and substituted with a second one from the same plant for another 48- to 72-h IAP to increase transmission efficiency. Eleven adults were tested individually for each genotype. After insect removal, the discs were floated on water in a 24 -well plate for $72 \mathrm{~h}$ to allow virus multiplication, then frozen. Maize was included as a control species not infectible by TSWV. Thrips rearing, transmission trials, and final incubation of discs in water all were performed in growth chambers at $26 \pm 1^{\circ} \mathrm{C}, 60 \%$ relative humidity and a cycle of $16 \mathrm{~h}$ light, $8 \mathrm{~h}$ dark. Total RNA was extracted from each leaf disc as described above and resuspended in $40 \mu \mathrm{l}$ of sterile water. TSWV replication was analyzed by spotting 10 and $1 \mu \mathrm{l}$ on membranes and hybridizing with the TSWV-NSm probe described above. Quality of RNA extractions was checked by amplifying a portion of the Rubisco L-gene with primers RBCL-H680 and RBCL-C1321 (18).

Mechanical inoculation assays. Hybrids were challenged with TSWV isolate P105 and with P105TS044/8V, a P105-derived isolate able to overcome the $T s w$ gene-derived conventional TSWV resistance in pepper (IVV collection; P. Roggero and M. Turina, personal communication). For long-term storage, isolates were kept in liquid nitrogen as aliquots of symptomatic leaves of Nicotiana benthamiana.

The assays were conducted in insect-proof glasshouses using leaf extracts to mechanically inoculate the viruses. Seed of tomato test plants (the three hybrids 30-4 $\times$ RT, 30-4 $\times$ INB, 30-4 $\times$ LH76PC, and the hybrid Valiente) were soaked overnight in sterile water and then sown in sterilized soil in 22-hole plastic trays. Seedlings were grown at $22^{\circ} \mathrm{C}$ until they reached the fourleaf stage $(\approx 1$ month after sowing). The inoculum was prepared from frozen aliquots of each virus isolate ground in extraction buffer $(50 \mathrm{mM}$ phosphate buffer, $\mathrm{pH} 7$, containing $5 \mathrm{mM}$ diethyldithiocarbamic acid-Na-salt [DIECA], $1 \mathrm{mM}$ ethylenediamine tetraacetic acid [EDTA], and $5 \mathrm{mM}$ sodium thioglycolate, plus activated charcoal at $0.5 \mathrm{mg} / \mathrm{ml}$ ) at $1: 10$ dilution (wt/vol) and then mechanically inoculated on young $N$. benthamiana plants. After 10 to 15 days, the young parts of the plants that showed systemic infection were ground in the same buffer $1 / 50(\mathrm{wt} / \mathrm{vol})$ and the extract was used immediately to inoculate test tomato plants. Considering that Tospovirus inoculum may quickly loose infectivity, control nontransgenic tomato cv. Marmande always were inoculated last.

Plants were observed weekly for symptom appearance. At 4 weeks postinoculation (wpi), an apical leaf was taken from each plant and tested for TSWV by enzyme-linked immunosorbent assay (ELISA). Plates were coated with a polyclonal serum to TSWV (A293 from IVV collection) and then revealed with $\mathrm{N}$ protein targeting Mab NUV-2 (25), followed by an alkalinephosphatase-conjugated anti-mouse antibody. The plants were maintained and monitored up to 6 wpi.

Grafting assays. TSWV-infected tomato plants (cv. Marmande) were used as rootstocks to wedge graft apical portions of different types of tomato: hybrids $30-4 \times \mathrm{INB}, 276 \times \mathrm{INB}$, and Valiente (carrying the $S w-5$ gene); the homozygous 30-4 line; and Marmande (susceptible control). Six plants were grafted for genotype. Symptoms were observed and leaf samples were collected from each scion 4 weeks post-grafting. Plants were monitored until 8 weeks post-grafting and, in some cases, young leaf samples also were collected. Total RNA was extracted from samples as described above and resuspended in $40 \mu \mathrm{l}$ of sterile water. TSWV infection was analyzed by dot blot hybridization 
with the TSWV-NSm probe described above. In particular cases, leaf squashes of young tomato leaves after 7 weeks post-grafting were done on nylon membranes and hybridized similarly.

\section{RESULTS}

Field experiments for virus resistance and agronomic performance. In the trial for resistance, TSWV infection was monitored five times throughout the duration of the experiment (Fig. 2). At the first survey (3 weeks from the beginning), 19 plants among nontransgenic hybrids $276 \times$ RT and $276 \times$ INB showed the typical symptoms of TSWV infection, including wilting of the apex, bronzing of leaves, and reduced size. Dot blots confirmed TSWV infection of these plants. Infection then increased with time, reaching, at the end of the experiment, 33.3 and $50 \%$ of the plants for $276 \times$ RT and $276 \times$ INB, respectively. Infected plants were present in all four blocks (Table 1). Among the transgenic hybrids 30-4 × RT, 30-4 × INB, and 30-4 × H76PC or the resistant commercial hybrid, no plants ever were found infected in dot blots or showed virus symptoms.

The highest level of thrips was found in the first survey, 9 days from the beginning of the trial, ranging between 2.38 and 8.84 insects per leaf (adults and larvae) on the hybrids 30-4 $\times$ INB and $276 \times$ RT, respectively (Table 2; Fig. 2B). The hybrids $276 \times$ RT and $276 \times$ INB were the most infested by thrips, but the amount of infestation did not differ significantly from that found on the corresponding transgenic hybrids, 30-4 $\times$ RT and 30-4 $\times$ INB. In the following surveys, thrips populations dramatically lowered, with mean densities $<1$ insect/leaf at 3 weeks, and close to zero at 7 weeks. No thrips were found on tomato plants at 10 weeks (Table 2). The thrips population was composed of $\approx 80 \% \mathrm{~F}$. occidentalis and 20\% Thrips tabaci Lindeman, another well-known TSWV vector.

Some generalist predators were able to colonize the experimental field throughout the duration of the trial. Particularly, three heteropteran species were found during the surveys: Macrolophus caliginosus Wagner, Dicyphus errans (Wolff) (Miridae), and Orius laevigatus (Fieber) (Anthocoridae). Among these species, M. caliginosus was the most abundant, with mean densities of individuals, both nymphs and adults, per leaf increasing from 0.38 ( 3 weeks) to 2.89 (10 weeks) (Table 2; Fig. 2B). In contrast, the other two species occurred only occasionally ( $<0.1$ individuals/leaf).

In the resistance trial (Table 1), the yield of two nontransgenic TSWV-infected hybrids was significantly lower (3.59 and $\left.3.48 \mathrm{~kg} / \mathrm{m}^{2}\right)$ than in the corresponding transgenic hybrids $(7.52$ and $\left.7.26 \mathrm{~kg} / \mathrm{m}^{2}\right)$.

In the trial for agronomic performance (Table 3), early and total production were analyzed separately, and productive parameters such as number of fruit per square meter, yield, and average fruit weight were determined. When each transgenic hybrid was compared with its nontransgenic counterpart, values were very similar and statistical analysis showed no significant differences. No

TABLE 1. Final results of the Albenga field assay for virus resistance ( 8 September) compared with total production and fruit weight data ${ }^{\mathrm{z}}$

\begin{tabular}{|c|c|c|c|c|c|c|c|}
\hline \multirow[b]{2}{*}{ Hybrid } & \multicolumn{4}{|c|}{ Blocks } & \multirow[b]{2}{*}{ Total no. infected plants (\%) } & \multirow[b]{2}{*}{ Total production $\left(\mathrm{kg} / \mathrm{m}^{2}\right)$} & \multirow[b]{2}{*}{ Fruit weight (g) } \\
\hline & I & II & III & IV & & & \\
\hline $30-4 \times \mathrm{RT}$ & 0 & 0 & 0 & 0 & $0(0)$ & $7.52 \mathrm{a}$ & $82.73 \mathrm{c}$ \\
\hline $276 \times \mathrm{RT}$ & 2 & 4 & 7 & 3 & $16(33.3)$ & $3.59 \mathrm{~b}$ & $88.93 \mathrm{bc}$ \\
\hline $30-4 \times$ INB & 0 & 0 & 0 & 0 & $0(0)$ & $7.26 \mathrm{a}$ & $96.85 \mathrm{ab}$ \\
\hline $276 \times$ INB & 2 & 8 & 7 & 7 & $24(50)$ & $3.48 \mathrm{~b}$ & $104.25 \mathrm{a}$ \\
\hline $30-4 \times \mathrm{H} 76 \mathrm{PC}$ & 0 & 0 & 0 & 0 & $0(0)$ & $6.90 \mathrm{a}$ & 89.95 bc \\
\hline Valiente & 0 & 0 & 0 & 0 & $0(0)$ & $6.77 \mathrm{a}$ & $93.35 \mathrm{bc}$ \\
\hline
\end{tabular}

${ }^{z}$ Within columns, values followed by the same letter are not significantly different (Tukey's test, $P \leq 0.05$ ).

TABLE 2. Densities of thrips vectors and of the predator Macrolophus caliginosus per leaf monitored in the field trial for virus resistance ${ }^{\mathrm{Z}}$

\begin{tabular}{|c|c|c|c|c|c|}
\hline Hybrid & 24 June & 8 July & 21 July & 2 August & 26 August \\
\hline \multicolumn{6}{|l|}{ Thrips per leaf } \\
\hline $30-4 \times \mathrm{RT}$ & $4.16 \pm 6.35 \mathrm{ab}$ & $0.54 \pm 0.90 \mathrm{a}$ & $0.06 \pm 0.24 \mathrm{a}$ & $0 \pm 0$ & $0 \pm 0$ \\
\hline $276 \times \mathrm{RT}$ & $8.84 \pm 11.23 \mathrm{a}$ & $0.73 \pm 1.07 \mathrm{a}$ & $0.10 \pm 0.31 \mathrm{a}$ & $0 \pm 0$ & $0 \pm 0$ \\
\hline $30-4 \times$ INB & $2.38 \pm 3.14 b$ & $0.56 \pm 0.99 \mathrm{a}$ & $0.13 \pm 0.39 a$ & $0 \pm 0$ & $0 \pm 0$ \\
\hline $276 \times$ INB & $7.25 \pm 11.07 \mathrm{ab}$ & $0.73 \pm 0.96 \mathrm{a}$ & $0.21 \pm 0.41 \mathrm{a}$ & $0 \pm 0$ & $0 \pm 0$ \\
\hline $30-4 \times \mathrm{H} 76 \mathrm{PC}$ & $6.31 \pm 5.98 \mathrm{ab}$ & $0.46 \pm 0.74 \mathrm{a}$ & $0.10 \pm 0.31 \mathrm{a}$ & $0.02 \pm 0.14$ & $0 \pm 0$ \\
\hline Valiente & $3.09 \pm 3.93 b$ & $0.90 \pm 1.34 \mathrm{a}$ & $0.25 \pm 0.53 \mathrm{a}$ & $0 \pm 0$ & $0 \pm 0$ \\
\hline \multicolumn{6}{|c|}{ M. caliginosus per leaf } \\
\hline $30-4 \times \mathrm{RT}$ & $\ldots$ & $0.50 \pm 0.88 \mathrm{a}$ & $0.31 \pm 0.55 b$ & $0.54 \pm 0.85 \mathrm{a}$ & $2.85 \pm 2.72 a b c$ \\
\hline $276 \times \mathrm{RT}$ & $\ldots$ & $0.06 \pm 0.25 \mathrm{a}$ & $0.77 \pm 0.88 \mathrm{ab}$ & $0.75 \pm 1.39 \mathrm{a}$ & $3.00 \pm 2.36 \mathrm{abc}$ \\
\hline $30-4 \times \mathrm{INB}$ & $\ldots$ & $0.50 \pm 0.95 \mathrm{a}$ & $0.90 \pm 0.88 \mathrm{a}$ & $0.44 \pm 0.65 \mathrm{a}$ & $3.42 \pm 2.53 \mathrm{ab}$ \\
\hline $276 \times \mathrm{INB}$ & $\ldots$ & $0.44 \pm 0.91 \mathrm{a}$ & $0.75 \pm 0.93 \mathrm{ab}$ & $0.71 \pm 0.94 \mathrm{a}$ & $1.94 \pm 2.07 \mathrm{c}$ \\
\hline $30-4 \times \mathrm{H} 76 \mathrm{PC}$ & $\ldots$ & $0.34 \pm 0.48 \mathrm{a}$ & $0.71 \pm 0.99 \mathrm{ab}$ & $0.54 \pm 0.77 \mathrm{a}$ & $3.92 \pm 2.72 \mathrm{a}$ \\
\hline Valiente & $\ldots$ & $0.41 \pm 0.76 \mathrm{a}$ & $0.44 \pm 0.58 \mathrm{ab}$ & $0.42 \pm 0.79 a$ & $2.21 \pm 2.00 \mathrm{bc}$ \\
\hline
\end{tabular}

${ }^{\mathrm{z}}$ Mean number \pm standard deviation for each date. Within columns, values followed by the same letter are not significantly different (Tukey's test; $P \leq 0.05$ ).

TABLE 3. Results of the field assay for agronomic performance in absence of Tomato spotted wilt virus infection: early and total production ${ }^{\mathrm{z}}$

\begin{tabular}{|c|c|c|c|c|c|c|}
\hline \multirow[b]{2}{*}{ Hybrid } & \multicolumn{3}{|c|}{ Early production } & \multicolumn{3}{|c|}{ Total production } \\
\hline & Fruit (no./m²) & Yield $\left(\mathrm{kg} / \mathrm{m}^{2}\right)$ & Fruit weight(g) & Fruit (no./m²) & Yield $\left(\mathrm{kg} / \mathrm{m}^{2}\right)$ & Fruit weight (g) \\
\hline $30-4 \times \mathrm{RT}$ & $9.4 \mathrm{c}$ & $0.93 \mathrm{~d}$ & $98.9 \mathrm{bc}$ & $61.0 \mathrm{ab}$ & $5.86 \mathrm{~b}$ & $96.1 \mathrm{c}$ \\
\hline $276 \times \mathrm{RT}$ & $11.1 \mathrm{c}$ & $1.00 \mathrm{~cd}$ & $90.3 \mathrm{c}$ & $61.8 \mathrm{a}$ & $5.73 \mathrm{~b}$ & $92.7 \mathrm{c}$ \\
\hline $30-4 \times$ INB & $14.6 \mathrm{~b}$ & $1.69 \mathrm{a}$ & $117.6 \mathrm{a}$ & $48.9 \mathrm{~d}$ & $5.29 \mathrm{c}$ & $108.6 \mathrm{ab}$ \\
\hline $276 \times$ INB & $14.9 \mathrm{ab}$ & $1.66 \mathrm{ab}$ & $112.0 \mathrm{ab}$ & $53.8 \mathrm{~cd}$ & $5.32 \mathrm{c}$ & $98.8 \mathrm{bc}$ \\
\hline $30-4 \times \mathrm{H} 76 \mathrm{PC}$ & $16.4 \mathrm{a}$ & $1.84 \mathrm{a}$ & $112.4 \mathrm{ab}$ & $55.7 \mathrm{bc}$ & $6.25 \mathrm{a}$ & $108.9 \mathrm{a}$ \\
\hline $276 \times \mathrm{H} 76 \mathrm{PC}$ & $15.2 \mathrm{ab}$ & $1.72 \mathrm{a}$ & $112.3 \mathrm{ab}$ & $56.0 \mathrm{abc}$ & $6.03 \mathrm{ab}$ & $107.6 \mathrm{ab}$ \\
\hline
\end{tabular}

z Within columns, values followed by the same letter are not significantly different (Duncan's test; $P \leq 0.05$ ). 
phenotypic differences were seen between each transgenic hybrid and its corresponding nontransgenic one.

Transgene flow evaluation. To monitor movement of the transgene via pollen, kanamycin-spray screening followed by the PCR analysis of the transgene in the kanamycin-tolerant seedlings was used. Nontransgenic control seedlings sprayed with kanamycin showed evident chlorotic spots on leaves after 15 days, whereas transgenic controls appeared unaffected. When the 10,071 seedlings deriving from nontransgenic plants were tested, 80 of them did not show chlorosis. Plants were analyzed by PCR, and the tomatospecific $(A P X)$ primers produced the 303-bp expected DNA fragment in all the 80 samples (Fig. 3A). When samples were analyzed with the TSWV-N-gene primers, the 273-bp expected DNA fragment was detected in 16 samples (Fig. 3B). This revealed that, of the 80 plants not showing chlorosis, only 16 were transgenic, whereas the rest were escapes of the kanamycin-spray screening.

The $16(0.32 \%)$ transgenic seedlings were detected exclusively in the 4,936 progeny seedlings of nontransgenic plants from the open field trial (Table 4). The distribution of these individuals in the field apparently was random in the nontransgenic elementary plots and in the border rows (Fig. 3C).

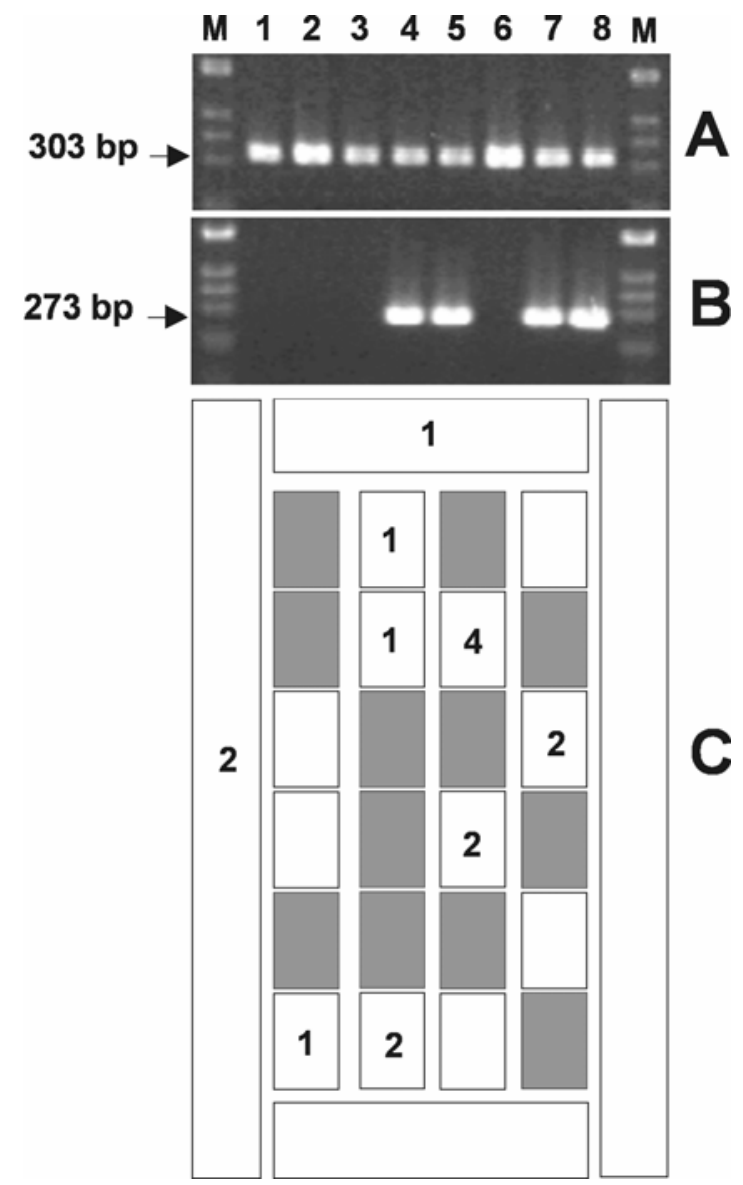

Fig. 3. Evaluation of transgene flow through pollen in the open field trial. A and B, Polymerase chain reaction analysis of a selection of eight DNA samples extracted from seedlings derived from nontransgenic plants following the kanamycin-tolerance test. A, Detection of tomato endogenous APX gene, showing that genomic DNA was amplifiable and $\mathbf{B}$, detection of the Tomato spotted wilt virus $-N$ transgene. $\mathrm{M}=1-\mathrm{kb}$ ladder (Invitrogen); arrows indicate the specific amplified DNA fragments. C, Scheme of field trials. The 24 elementary plots (rectangles) were $5 \mathrm{~m}^{2}$ in size and each one consisted of 12 tomato plants belonging to the same hybrid. The plots were organized in four randomized blocks in which the three transgenic and the three nontransgenic hybrids were arranged. All around the 24 plots, border rows of nontransgenic tomato hybrids were present (long rectangles), divided into four sections. Gray rectangles $=$ transgenic plots. White rectangles $=$ nontransgenic plots. Figures in the rectangles indicate the number of seedlings positive for transgene integration (16 seedlings total).
The gene flow in the open field trial apparently was not the same for the three different harvests (Table 5) because the crosspollination frequency, revealed by the gene flow data, was higher in the last two harvests (seven cases on 26 August and seven on 8 September) than in the first (two cases on 10 August). In the two protected crop trials, no transgenic seedlings were detected in the progeny of nontransgenic plants.

The progeny of transgenic plants also were analyzed and $\approx 75 \%$ of the seedlings derived from these plants were not affected by the kanamycin treatment, indicating the presence of the nptII transgene (Table 4). These data fit well with the expected 3:1 Mendelian inheritance of a dominant character in the essentially selfed progeny of a hybrid population.

Leaf disc infection assays. Each genotype was tested with 11 thrips. Each case is the result of challenging two discs from a single plant with a single thrips. An inoculation was considered positive if either one or both discs sustained detectable TSWV replication. In the dot blot analysis of the RNAs from the leaf discs (Fig. 4), no TSWV-specific signal was detected with the nonhost plant (maize), demonstrating that the amount of virus injected by the thrips is not sufficient, unless replication occurs, to produce a signal. When a susceptible tomato was used $(276 \times$ INB hybrid), TSWV was detected in most cases (8 of 11), indicating that this assay was able to reveal virus replication. For the commercial hybrid containing the $S w-5$ resistance gene, 7 positives out of 11 were detected. In no case was virus replication detected in the homozygous and hybrid 30-4 plants. All RNA extracts contained amplifiable RNA, as demonstrated by the PCR for the Rubisco L gene (data not shown).

Resistance of the hybrid progeny upon mechanical inoculation. Natural inoculum pressure in the field assay was not very high (33 to $50 \%$ of the susceptible plants were infected), and legal restrictions applied to field tests of transgenic crops in Italy in year 2000 prevented repetition of the field experiment; therefore, further resistance tests were performed under laboratory conditions. TSWV was mechanically inoculated onto very young seedlings to raise the infection rate. Using this technique, almost $100 \%$ of the nontransgenic controls were infected (30 of 31 plants), as indicated by development of chlorotic and necrotic lesions on inoculated leaves from $1 \mathrm{wpi}$, and then systemic symptoms (stopping of growth, wilting of the apex, and bronzing of

TABLE 4. Percentage estimations of transgenic (T) seedlings over the total number of seedlings tested for each case ${ }^{\mathrm{z}}$

\begin{tabular}{lrrrrr}
\hline & \multicolumn{2}{c}{ Resulted in } & & \\
\cline { 2 - 3 } Seedlings, trial & $\mathrm{T}$ & $\mathrm{NT}$ & & Total & T/total $(\%)$ \\
\hline T plants & & & & \\
$\quad$ Protected crop A & 1,779 & 608 & & 2,387 & 74.53 \\
$\quad$ Open field & 2,819 & 917 & & 3,736 & 75.46 \\
NT plants & & & & \\
$\quad$ Protected crop A & 0 & 2,958 & & 2,958 & 0.00 \\
Protected crop M & 0 & 2,177 & & 2,177 & 0.00 \\
Open field & 16 & 4,920 & & 4,936 & 0.32 \\
\hline
\end{tabular}

z Globally, 16,194 seedlings were tested using kanamycin tolerance test. Results for nontransgenic (NT) plants also were confirmed by transgenespecific polymerase chain reaction. Protected crop A: trial in Albenga, northern Italy; protected crop M: trial in Monsampolo, central Italy.

TABLE 5. Transgenic progeny seedlings obtained from nontransgenic plants collected in the open-field trial ${ }^{\mathrm{z}}$

\begin{tabular}{lcc}
\hline Harvest & T progeny/total & Percent \\
\hline First, 10 August 1999 & $2 / 1,663$ & 0.120 \\
Second, 26 August 1999 & $7 / 1,664$ & 0.421 \\
Third, 8 September1999 & $7 / 1,609$ & 0.435 \\
Total & $16 / 4,936$ & 0.324 \\
\hline
\end{tabular}

${ }^{\mathrm{z}}$ Data are shown for the three harvests. 
young leaves) from 2 to 3 wpi. Among the 114 transgenic hybrids tested (42 plants of 30-4 $\times$ RT, 47 plants of $30-4 \times$ INB, and 25 plants of 30-4 $\times$ H76PC), no infection was detected throughout the experiment (6 wpi) based on visual observation or ELISA. The Valiente hybrid (six plants) also showed no systemic infection.

When seven 30-4 $\times$ INB plants were challenged with the $T s w$ resistance-breaking strain P105TS044/8V, no infection was detected, whereas nontransgenic controls (nine plants) developed systemic mosaic and stunting. Two of eight $S w 5$-containing Valiente plants showed systemic necrosis and tested positive at the TSWV-specific ELISA.

Grafting assays. In dot blot assays (data not shown), all nontransgenic hybrid $(276 \times$ INB) and susceptible Marmande plants were TSWV infected and showed typical symptoms 4 weeks after grafting on TSWV-infected tomato. All plants of the transgenic hybrid and the homozygous 30-4 line were negative in dot blot and did not show any symptoms throughout the duration of the experiment ( 8 weeks). In the case of plants carrying the $S w-5$ resistance gene, one of six plants was infected 4 weeks after grafting, and three of six plants showed necrotic spots on young leaves 7 weeks after grafting. Leaf-squash assays showed that these necrotic spots corresponded to TSWV infection sites (Fig. 5).

\section{DISCUSSION}

The transgenic tomato hybrids challenged in this study, either in field or laboratory conditions, did not develop any disease symptoms and did not contain any detectable amount of virus. Because of the lack of detectable replication in the primary infection sites observed in leaf disc assays and the absence of any infection in grafting experiments, we propose that the "high resistance" observed actually could constitute functional immunity. This is in contrast to resistance in the commercial hybrid containing the $S w-5$ gene which is due to hypersensitivity response $(4,7)$. This was confirmed by our results with leaf discs and graftings.

Different resistance mechanisms also are indicated by inoculation experiments with TSWV P105TS044/8V, the resistancebreaking strain, because this strain did not overcome the 30-4 resistance, but infected some plants carrying the $S w-5$ gene. TSWV resistance-breaking strains have been reported previously in $S w$-5-tomato cultivars $(2,14)$ and constitute a concern about durability of resistance in the field based on this gene. Even if $T s w$ (in pepper) and $S w-5$ resistance genes do not appear to interact with the virus in the same way, both gene products interact with the same or essentially similar downstream processes that result in expression of resistance (12).

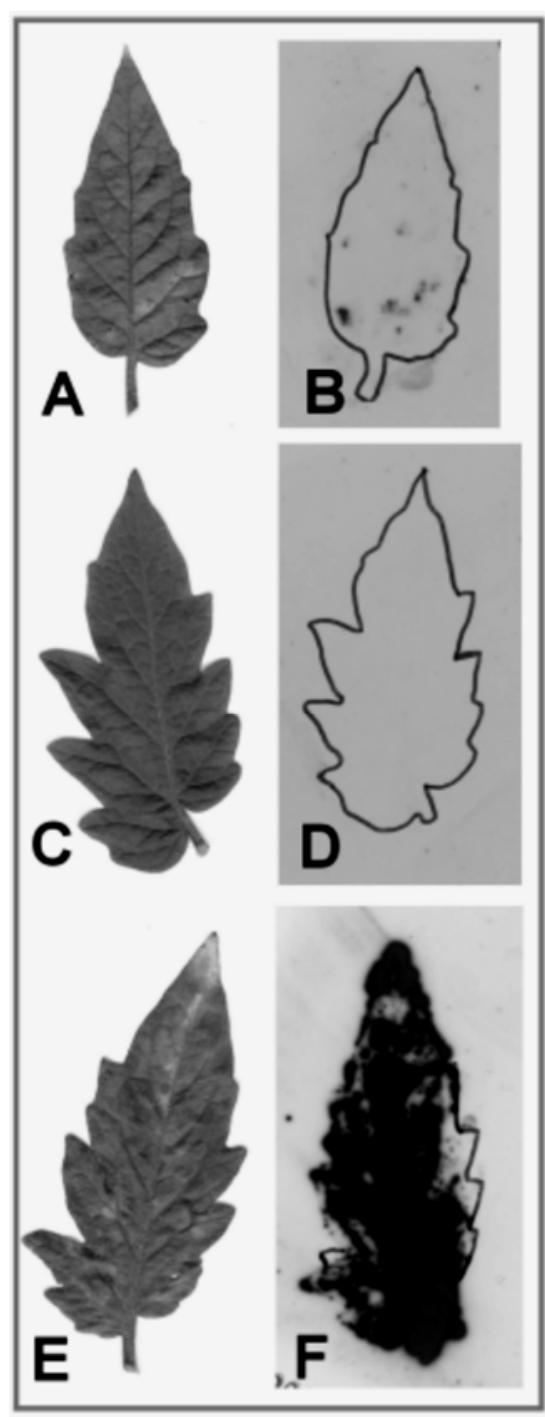

Fig. 5. Tomato spotted wilt virus (TSWV) infection of tomato scions in grafting experiments. A, C, and $\mathbf{E}$, Young tomato leaves from transgenic and nontransgenic scions, collected 7 weeks after grafting on TSWV-infected tomato rootstocks, were squashed on a nylon membrane, which $\mathbf{B}, \mathbf{D}$, and F, was hybridized with a TSWV-NSm probe. A and B, Valiente hybrid, $\mathbf{C}$ and D, 30-4 homozygous transgenic line, and $\mathbf{E}$ and $\mathbf{F}$, nontransgenic hybrid $276 \times$ INB.

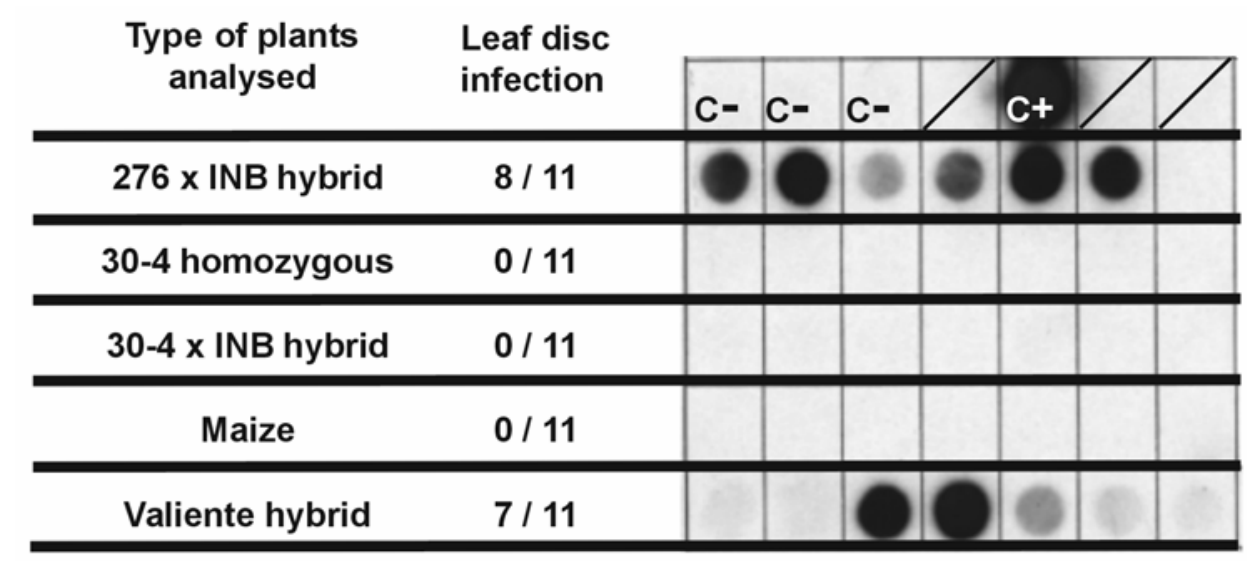

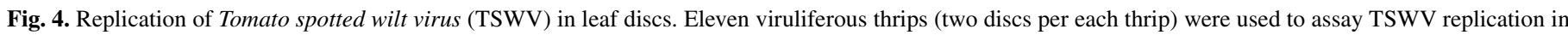

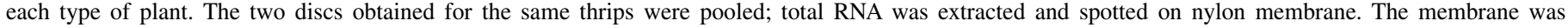

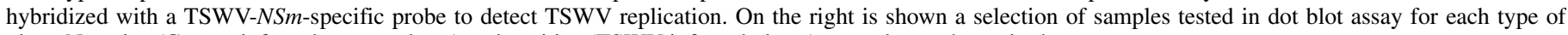
plant. Negative (C-, noninfected tomato plants) and positive (TSWV-infected plants) controls are shown in the upper row. 
The presence of the transgene in the hemizygous state appeared to be as efficient as at the homozygous state in preventing virus infection. This is essential for determining the practical utility of the gene in commercial hybrids. Field tests with the transgenic hybrids grown together with their corresponding nontransgenic hybrids demonstrated the effects of the transgene in the same genetic background. These results indicate that the presence of 30-4 transgene has no other evident effect on the plant performance, apart from TSWV resistance. In a recent proteomic study with tomato hybrid 30-4 $\times$ RT and its corresponding nontransgenic $276 \times$ RT (6), no significant differences, either qualitative or quantitative, were detected by two-dimensional electrophoresis, indicating that expression of major proteins was unmodified by the genetic manipulation. During the field test, the nontransgenic plants did not reach $100 \%$ TSWV infection, a condition frequently occurring in assays subjected to environmental conditions. This may be due partly to the population of vectors which were present essentially in the first part of the experiment, whereas their number fell dramatically later, as a consequence of the increase in the population of predators not disturbed by insecticide spraying (Table 3). Although the use of sequences derived from TSWV to introduce resistance dates back to 1991 on model plants $(1,9)$, limited literature is available on tomato. Two reports $(13,31)$ describe tomato plants transformed with the TSWV $N$ gene. Kim and coworkers (13) could obtain only partial protection to virus infection, whereas Ultzen and coworkers (31) selected one transgenic line whose homozygous and hybrid progeny was resistant. These plants were tested only in laboratory conditions by mechanical inoculation. De Haan et al. (7) tested TSWV-N transgenic tomato hybrids and $S w$-5-derived hybrids for resistance under laboratory and field conditions and highlighted the difference in the resistance obtained with $S w-5$ and TSWV- $N$ genes. However, for the resistance assays, they selected plants expressing the transgenic $\mathrm{N}$ protein, whereas our 30-4 progeny and hybrids were not expressors. Recently, Gubba et al. (10) have reported a combination of transgenic and natural resistance to TSWV in tomato. Those transgenic plants expressed the TSWV N protein and, therefore, the resistance mechanism was very likely protein mediated, unlike the mechanism observed in our plants.

There is concern that release of transgenic plants into the environment could allow transfer of the inserted transgenes to neighboring crops. Although tomato is a mostly self-pollinating crop $(5,15,22,24,26)$, we determined the flow of transgenic DNA through pollen by analyzing the progeny obtained from the nontransgenic tomato plants present in field tests. The preliminary kanamycin selection step, followed by a search for the transgenic DNA, allowed us to analyze several thousand plants with relatively limited cost and effort. In this respect, the ban on antibiotic resistance genes in transgenic plants imposed by the new regulation in the European Union (EU directive 2001/18) could complicate future work on transgene flow, particularly in species like tomato with low cross-pollination rates.

There are, in fact, very few reports about transgene flow in tomato. In a recent study (11), no transgene flow was detected after analyzing $\approx 5,000$ seedlings from fruit of nontransgenic tomato plants grown in trials of virus-resistant transgenic tomato. In our experiments, in the crops isolated from the environment by plastic and insect-proof nets, no transgene flow was detected; whereas, in the open field, $0.32 \%$ of the progeny of nontransgenic plants contained transgenic DNA (Tables 4 and 5). The same seed batches were used in all trials; therefore, field trial transgenic seedlings likely resulted from pollinator activity. Studies on tomato pollen dispersal indicate that pollinating insects are much more important than wind dispersal $(3,21,23)$. Pollinator activity varies seasonally, being limited at the beginning of flowering, peaking during summer, and decreasing in autumn $(21,23)$. This might explain the differences observed between the first harvest $(0.12 \%$ of transgenic seedlings) and the two following ones $(\approx 0.4 \%)$.
The limited transgene flow detected in our open field trial is in agreement with the percentages ( 0.5 to $10 \%)$ of cross-pollination reported for tomato. Further and more focused experiments are needed to establish the safety distances or barriers required for transgenic tomato crops in order to minimize risks and assess appropriate safety procedures.

Due to the high economic value of tomato crops worldwide and the importance of TSWV in several countries, the engineered resistance described here is of practical value for breeding into cultivars of commercial interest, because it is active also at the hemizygous state both in field and laboratory conditions and does not change the agronomic characteristics of the plants. Moreover, due to the ability of the 30-4 transgene to early block virus replication, its breeding into a line containing a naturally occurring resistance gene could produce plants where two different TSWV resistance mechanisms are active, thus greatly reducing the ability of the virus to develop resistance-breaking strains.

\section{ACKNOWLEDGMENTS}

This research was funded in part by the Italian Ministry of Agriculture and Forest Policy (MiPAF), in the framework of the "Vegetable Crops" National Project (paper no. 42). G. P. Accotto and A. M. Vaira contributed equally to this work. We thank V. Lisa, P. Roggero, and M. Turina (Torino, Italy) for providing TSWV isolates; G. Minuto (Albenga, Italy) for providing priceless help and assistance in the field test for virus resistance; and A. Garzino-Demo for critical reading of the manuscript.

\section{LITERATURE CITED}

1. Accotto, G. P., Allavena, A., Vaira, A. M., and Nervo, G. 2000. Inserting the nucleoprotein gene of tomato spotted wilt virus in different plant species, and screening for virus resistance. Pages 148-153 in: Plant Genetic Engineering: Towards the Third Millennium. A. D. Arencibia, ed. Elsevier, Amsterdam.

2. Aramburu, J., and Martí, M. 2002. The occurrence in north-east Spain of a variant of Tomato spotted wilt virus (TSWV) that breaks resistance in tomato (Lycopersicon esculentum) containing the $S w-5$ gene. New Dis. Rep. Vol. 6.

3. Bin, F., and Soressi, G. P. 1973. Insetti pronubi e produzione di seme ibrido di pomodoro. Genet. Agrar. 1:35-74.

4. Cho, J. J., Custer, D. M., Watterson, J. C., and Wyatt, C. 1992. Development of TSWV-resistant commercial tomato. Eighth Annu. Tomato Dis. Workshop, Columbus, $\mathrm{OH}$.

5. Clayberg, C. D. 1959. Observations on the effectiveness of natural crosspollination. Tomato Gen. Coop. Rep. 9:27-28.

6. Corpillo, D., Gardini, G., Vaira, A. M., Aime, S., Accotto, G. P., and Fasano, M. 2004. Proteomics as a tool to improve investigation of substantial equivalence in genetically modified organisms: the case of a virus-resistant tomato. Proteomics 4:193-200.

7. De Haan, P., Ultzen, T., Prins, M., Gielen, J., Goldbach, R., and van Grinsven, M. 1996. Transgenic tomato hybrids resistant to Tomato spotted wilt virus infection. Acta Hortic. 431:417-426.

8. Elliot, R. M., Bouloy, M., Calisher, C. H., Goldbach, R., Moyer, J. T., Nichol, S. T., Pettersson, R., Plyusnin, A., and Schmaljohn, C. S. 2000. Tospovirus. Pages 617-621 in: Virus Taxonomy-Seventh Report of the International Committee on Taxonomy of Viruses. M. H. V. Van Regenmortel, ed. Academic Press, New York.

9. Gielen, J. J. L., de Haan, P., Kool, A. J., Peters, D., van Grinsven, M. Q. J. M., and Goldbach, R. W. 1991. Engineered resistance to tomato spotted wilt virus, a negative-strand RNA virus. Bio/Technology 9:1363-1367.

10. Gubba, A., Gonsalves, C., Stevens, M. R., Tricoli, D. M., and Gonsalves, D. 2002. Combining transgenic and natural resistance to obtain broad resistance to tospovirus infection in tomato (Lycopersicon esculentum mill). Mol. Breed. 9:13-23.

11. Ilardi, V., and Barba, M. 2001. Assessment of functional transgene flow in tomato fields. Mol. Breed. 8:311-315.

12. Jahn, M., Paran, I., Hoffmann, K., Radwanski, E. R., Livingstone, K. D., Grube, R. C., Aftergoot, E., Lapidot, M., and Moyer, J. 2000. Genetic mapping of the Tsw locus for resistance to the Tospovirus Tomato spotted wilt virus in Capsicum spp. and its relationship to the $S w-5$ gene for resistance to the same pathogen in tomato. Mol. Plant-Microbe Interact. 13:673-682.

13. Kim, W. J., Sun, S. S. M., and German, T. L. 1994. Disease resistance in tobacco and tomato plants transformed with the tomato spotted wilt virus nucleocapsid gene. Plant Dis. 78:615-621. 
14. Latham, L. J., and Jones, R. A. C. 1998. Selection of resistance breaking strains of tomato spotted wilt tospovirus. Ann. Appl. Biol. 133:385-402.

15. Lesley, J. W. 1924. Cross-pollination of tomatoes. J. Hered. 15:233-235.

16. Louro, D., Accotto, G. P., and Vaira, A. M. 2000. Occurrence and diagnosis of Tomato chlorosis virus in Portugal. Eur. J. Plant Pathol. 106:589592.

17. Mason, G., Provero, P., Vaira, A. M., and Accotto, G. P. 2002. Estimating the number of integrations in transformed plants by quantitative real-time PCR. BMC Biotechnol. Oct 24:2(1):20.

18. Nassuth, A., Pollari, E., Helmeczy, K., Steward, S., and Kofalvi, S. A. 2000. Improved RNA extraction and one-tube RT-PCR assay for simultaneous detection of control plant RNA plus several viruses in plant extracts. J. Virol. Methods 90:37-49.

19. Nervo, G., Cirillo, C., Accotto, G. P., and Vaira, A. M. 2003. Characterisation of two tomato lines highly resistant to TSWV following transformation with the viral nucleoprotein gene. J. Plant Pathol. 85:139-144.

20. Parrella, G., Gognalons, P., Gebre-Selassiè, K., Vovlas, C., and Marchoux, G. 2003. An update of the host range of Tomato spotted wilt virus. J. Plant Pathol. 85:227-264.

21. Richardson, R. W., and Alvarez, E. L. 1957. Pollination relationships among vegetable crops in Mexico. I. Natural cross pollination in cultivated tomatoes. Proc. Am. Soc. Hortic. Sci. 69:366-371.

22. Rick, C. M. 1949. Rates of natural cross-pollination of tomatoes in various localities in California as measured by the fruit and seed set on male sterile plants. Proc. Am. Soc. Hortic. Sci. 54:237-252.

23. Rick, C. M. 1950. Pollination relations of Lycopersicon esculentum in native and foreign regions. Evolution 4:110-122.

24. Rick, C. M. 1958. NCP in cultivated tomatoes from the Chile-Perù frontier. Tomato Gen. Coop. Rep. 8:31.
25. Roggero, P., Ciuffo, M., Vaira, A. M., and Milne, R. G. 1998. Rapid purification of tospovirus nucleocapsids for antibody production and RNA analysis. Pages 25-28 in: Fourth Int. Symp. Tospoviruses and Thrips in Floral and Vegetable Crops, Wageningen, The Netherlands.

26. Soressi, G. P., and Bin, F. 1970. Some indications on tomato NCP by insects in Piacenza area (Italy) in view of hybrid seed production. Tomato Gen. Coop. Rep. 20:60-61.

27. Stevens, M. R., Scott, S. J., and Gergerich, R. C. 1992. Inheritance of a gene for resistance to Tomato spotted wilt virus (TSWV) from Lycopersicon peruvianum Mill. Euphytica 59:9-17.

28. Tashiro, H. 1967. Self-watering acrylic cages for confining insects and mites on detached leaves. J. Econ. Entomol. 60:354-356.

29. Tedeschi, R., Ciuffo, M., Mason, G., Roggero, P., and Tavella, L. 2001. Transmissibility of four tospoviruses by a thelytokous population of Thrips tabaci from Liguria, northwestern Italy. Phytoparasitica 29(1):37-45.

30. Thompson, G. J., and van Zijl, J. J. B. 1996. Control of Tomato spotted wilt virus in tomatoes in South Africa. Acta Hortic. 431:379-384.

31. Ultzen, T., Gielen, J., Venema, F., Westerbroek, A., de Haan, P., Tan, M.L., Schram, A., van Grinsven, M., and Goldbach, R. 1995. Resistance to tomato spotted wilt virus in transgenic tomato hybrids. Euphytica 85:159168.

32. Vaira, A. M., Semeria, L., Crespi, S., Lisa, V., Allavena, A., and Accotto, G. P. 1995. Resistance to Tospoviruses in Nicotiana benthamiana transformed with the $N$ gene of tomato spotted wilt virus: correlation between transgene expression and protection in primary transformants. Mol. PlantMicrobe Interact. 8:66-73.

33. Wijkamp, I., Almarza, N., Goldbach, R., and Peters, D. 1995. Distinct levels of specificity in thrips transmission of tospoviruses. Phytopathology $85: 1069-1074$. 